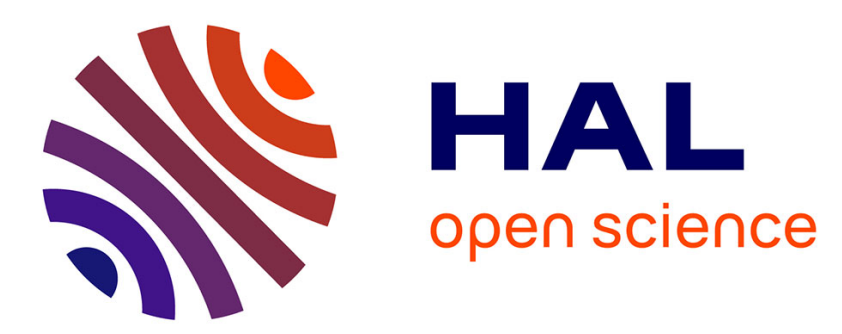

\title{
Management of raspberry and strawberry grey mould in open field and under protection. A review
}

$\mathrm{Xu}$, Wedgwood, Angela Berrie, Allen, Tim O’Neill

\section{To cite this version:}

Xu, Wedgwood, Angela Berrie, Allen, Tim O'Neill. Management of raspberry and strawberry grey mould in open field and under protection. A review. Agronomy for Sustainable Development, 2012, 32 (2), pp.531-543. 10.1007/s13593-011-0032-2 . hal-00930503

\section{HAL Id: hal-00930503 https://hal.science/hal-00930503}

Submitted on 1 Jan 2012

HAL is a multi-disciplinary open access archive for the deposit and dissemination of scientific research documents, whether they are published or not. The documents may come from teaching and research institutions in France or abroad, or from public or private research centers.
L'archive ouverte pluridisciplinaire HAL, est destinée au dépôt et à la diffusion de documents scientifiques de niveau recherche, publiés ou non, émanant des établissements d'enseignement et de recherche français ou étrangers, des laboratoires publics ou privés. 


\title{
Management of raspberry and strawberry grey mould in open field and under protection. A review
}

\author{
Xiangming Xu • Erika Wedgwood • Angela M. Berrie • \\ Janet Allen • Tim M. O’Neill
}

Accepted: 24 January 2011 /Published online: 26 May 2011

(C) INRA and Springer Science+Business Media B.V. 2011

\begin{abstract}
Grey mould, caused by Botrytis cinerea, is one of the most important diseases of strawberry and raspberry. In the UK, the majority of raspberry and strawberry production has recently switched to cropping under polythene tunnels. Although the risk of grey mould is greatly reduced under protection, a similar strategy is still adopted to manage grey mould on these crops. We first reviewed published studies on the epidemiology of grey mould on raspberry and strawberry, most of which are for crops grown in open field: (1) inoculum source comprises sclerotia on plant debris, plant organs and weeds, and resting mycelia on plant tissues. (2) Infection of flowers and the establishment of quiescent mycelium in floral parts is one of the main avenues for the rotting of ripe fruits. Thus, control of grey mould in open-field crops relies heavily on the scheduled application of fungicides during the flowering and early fruiting periods. (3) Recent research suggested possibility of $B$. cinerea as an endophyte. We carried out studies to understand the infection of flowers and fruit by $B$. cinerea on raspberry and strawberry crops grown under protection in order to assess whether management strategies developed for open crops are appropriate for crops grown under protections. Our main findings are: (1) covering crops early in the season did not significantly affect the incidence of raspberry fruit with latent infection
\end{abstract}

X. Xu $(\bowtie) \cdot$ A. M. Berrie

East Malling Research,

New Road, East Malling,

West Malling ME19 6BJ, UK

e-mail: xiangming.xu@emr.ac.uk

E. Wedgwood · J. Allen • T. M. O’Neill

ADAS Boxworth,

Battlegate Road, Boxworth,

Cambs CB23 4NN, UK by $B$. cinerea at harvest but reduced latent infection in strawberry. (2) Models developed for strawberry crops grown in the open did not give reliable predictions of flower infections on both strawberry and raspberry grown under protection. It was not possible to develop a predictive model for flower infection on raspberry grown under protection. (3) The level of ripe fruit with visual symptoms at harvest was low, usually close to zero. (4) Nearly all fruits from both sprayed and unsprayed crops were colonised by several fungi, including $B$. cinerea, within 7 days of harvest when stored at room temperatures. Based on these results, we question the value of scheduled fungicide applications to flowers and fruit for grey mould control under protection, and suggest that post-harvest fruit management, e.g. rapid cooling, is the key to prevent fruit from developing fungal rots before consumption.

Keywords Botrytis cinerea $\cdot$ Raspberry · Strawberry · Protection · Flower infection · Grey mould

\section{Contents}

1. Introduction. . . . . . . . . . . . . . . 2

2. Epidemiology of grey mould in open-field conditions .2

2.1. Inoculum sources and dispersal . . . . . . . 2

2.2. Infection pathways . . . . . . . . . 3

2.3. Infection conditions . . . . . . . . . . . 3

2.4. Recent development in related research on $B$. cinerea ........................4

3. Materials and methods ............... 4

3.1. Flower infection ................ 4

3.2. Occurrence of latent infection, and visual and postharvest grey mould ................ 4

3.3. Data analysis .............. 5 
4. Results . . . . . . . . . . . . . . . . . . . . .6

4.1. Raspberry . . . . . . . . . . . . 6

4.1.1. Infections of flowers . . . . . . . 6

4.1.2. Latent $B$. cinerea infection and grey mould on raspberry fruit . . . . . . . . . . 7

4.2. Strawberry . . . . . . . . . . . . 8 4.2.1. Infections of strawberry flowers .. . . . 8 8

4.2.2. Latent $B$. cinerea infection and grey mould on strawberry fruit . . . . . . . 9

5. Discussion . . . . . . . . . . . . . . . . . .9

5. Acknowledgment .................... . 12

6. References ........................... 12

\section{Introduction}

Grey mould of strawberry, caused by Botrytis cinerea Pers.: Fr., is one of the most important airborne diseases of strawberry and can seriously reduce yield and post-harvest quality (Sutton 1998). Similarly, raspberry fruit are very susceptible to $B$. cinerea, resulting in serious yield losses (McNicol et al. 1985). The fungus can also cause disease on raspberry canes, namely cane botrytis, which may lead to nodal lesions, impaired axillary growth and lateral shoot failure in spring (Williamson and Jennings 1986). Much research has been conducted on the epidemiology and management of strawberry grey mould in open-field crops. Current control of grey mould in commercial strawberry and raspberry production in the UK still relies heavily on the scheduled application of fungicides during the flowering and early fruiting periods.

In the UK, both raspberry and strawberry are now mostly grown under protection, usually Spanish tunnels, to extend the production season. However, nearly all published research studies on raspberry and strawberry grey mould to date are for crops grown in the open. The risk of grey mould is greatly reduced under protection, compared with open-field (Xiao et al. 2001; Evenhuis and Wanten 2006), which is primarily due to the protection of crops from rainfall, thereby reducing risks associated with flower and fruit infection. Nevertheless, control of grey mould on strawberry and raspberry grown under protection is still often based on the strategy developed for open-field crops, i.e. scheduled applications of fungicides during the flowering and early fruiting period. Research is needed to assess whether this approach for grey mould management on crops grown under protection is justified.

This paper consists of two parts. Firstly, we briefly review epidemiology of grey mould on raspberry and strawberry, mainly from studies conducted on open-field crops. Secondly, we report results from recent research studies of grey mould on raspberry and strawberry grown under protection in the UK. The central hypothesis of these studies is that the risk of grey mould on raspberry and strawberry crops covered with plastics early in the spring is much reduced and that the incidence of visual grey mould at harvest is very low on unsprayed crops. Data on flower infection by $B$. cinerea, latent $B$. cinerea infection on unripe fruit, grey mould at harvest, and post-harvest grey mould were collected from controlled field studies and fruit samples from commercial plantations.

\section{Epidemiology of grey mould in open-field conditions}

\subsection{Inoculum sources and dispersal}

There is a general consensus that inoculum sources comprise sclerotia on plant debris, plant organs and weeds, and resting mycelia on several plant tissues. Nevertheless, the relative importance of these potential inoculum sources may vary greatly with regions as well as with growing systems.

In Scotland, viable sclerotia observed throughout the year on dead leaves, petioles and stolons, and unpicked infected fruits, were identified to be an important source of inoculum for strawberry and raspberry (Jarvis 1962a, b, c). Most stem lesions on raspberry are believed to follow infection of leaves (Hockey 1952; Williamson 1991) but this is not supported by recent findings (O'Neill et al. 2009; $\mathrm{Xu}$ et al. 2009). Colonisation of leaves and petioles leading to cane infection was rare and direct infection of canes may be more likely. Prominent sclerotia form beneath the epidermis of canes during winter and erupt in spring. During periods of high humidity, these sclerotia become covered with conidia, an important inoculum source for infection of flowers (Jennings and Carmichael 1975). But recent unpublished observations at East Malling Research suggested that many of the sclerotia had shrivelled and failed to sporulate in early spring before flowering of raspberry because of the warm and dry conditions within the tunnel.

B. cinerea was the predominant fungus on the surface of the washed strawberry green leaves without disease symptoms (Kerling 1964), suggesting that conidia can infect green leaves but remain quiescent. This was confirmed by detailed inoculation studies of developing strawberry leaves (Braun and Sutton 1988). However, the infected leaves do not show visible symptoms before leaf senescence and the latent infection does not accelerate leaf senescence. In Ontario, Canada, dead strawberry leaves were the main source of inoculum, especially mycelium in the leaf laminae rather than in the leaf petioles (Braun and Sutton 1987); few sclerotia were recovered from plant residues or soils in the strawberry fields. The importance of 
leaf debris as an overwintering inoculum has been further confirmed in a sanitation experiment (Mertely et al. 2000).

In Norway, overwintered plant debris within strawberry planting beds were the main source of inoculum (Stromeng et al. 2009), including senescing and dead leaf laminae, stem residues (i.e., petioles, stolons, inflorescences), and mummified fruit. The importance of sclerotia relative to mycelia varied greatly between fields and years. In the annual cropping system with waiting-bed transplants in the Netherlands, however, necrotic leaves were not a significant source of inoculum (Boff et al. 2001).

Conidia of $B$. cinerea can be released and dispersed by both air movement and rain splash. A marked diurnal periodicity in airborne spores was observed in a Scottish raspberry plantation with peaks at mid-day and in the evening (frequently related to the rapid changes of rh and rainfall) but not for conidia trapped in strawberry plantations (Jarvis 1962a, b, c). A diurnal pattern of airborne conidia concentrations was also observed on annual crops of strawberry inside tunnels (Blanco et al. 2006). Fruit picking is also associated with peaks of spore dispersal. In contrast, another study reported that most spores were caught just above the strawberry canopy in periods of high humidity, regardless of rain or time of day (Miller and Waggoner 1957).

Concentrations of daily airborne conidia in an open-field plantation varied greatly with year and significantly correlated positively with temperature and rh in some years, and negatively with current duration of surface wetness but positively with wet conditions during the preceding days (Xu et al. 2000). However, the precise period of wet conditions that had most influenced the number of airborne conidia varied greatly with years.

\subsection{Infection pathways}

It is generally accepted that infection of strawberry flowers and the establishment of quiescent mycelium in floral parts is one of the primary avenues for the rotting of ripe fruits (Hennebert and Gilles 1958; Powelson 1960; Jarvis 1962a, b, c; Jarvis and Borecka 1968; Bristow et al. 1986). A majority of strawberry fruit infections is of the stem-end type (Powelson 1960; Jarvis 1962a, b, c; Haegermark 1984). The stem-end or neck portion of the receptacle is infected from infected stamens and the calyx with invasion being internal through these tissues rather than by contact of the infected floral parts with the fruit surface (Powelson 1960). Dry conidia can readily germinate on strawberry stigmas and hyphae can grow down the transmitting tissues of the styles (Bristow et al. 1986). Stamens are believed to be an important source of latent infection of strawberry fruit. But on raspberry, conidia can infect and colonise the transmitting tissues of the styles and the young carpels
(McNicol et al. 1985). It was speculated that the transition of mycelium from a quiescent to an aggressive phase on strawberry is hastened by increased water content (Jarvis 1964). However, Haegermark (1984) attributed most stemend types of infection to the direct penetration of the receptacle epidermis, although it was not clear whether the direct penetration of epidermis is due to germ tubes or hyphae originating from infected stamens. Fruit rots other than the stem-end type are few (Jarvis 1962a, b, c; Haegermark 1984). The low incidence of this type of infection may be due to the fact that a water film here often does not persist long enough for conidia to penetrate the epidermis.

\subsection{Infection conditions}

Strawberry pollen was found to have stimulatory effects on conidial germination and subsequent germ tube elongation (Borecka and Millikan 1973), but this effect was not observed in a UV microscopy study (Bristow et al. 1986). The open flower, white bud and senescent flower stages are most susceptible to infection, but infections at the white bud stage are much less likely to lead to grey mould than at the open flower stage (Jarvis and Borecka 1968). Green fruit is very resistant, white fruit is moderately resistant whereas ripe fruit is extremely susceptible to infection (Gilles 1959; Kovacs 1968).

The incidence of fruit infection is highly correlated with the pre-harvest (6-30 days) durations of $\mathrm{rh}>80 \%$ and the amount of pre-harvest (11-30 days) rainfall (Jarvis 1962a, b, c), indicating the importance of weather conditions on the level of grey mould. In particular, the durations of $\mathrm{rh}>80 \%$ and $>90 \%$ and surface wetness at $15-25^{\circ} \mathrm{C}$ during the bloom period is correlated strongly with fruit infection (Wilcox and Seem 1994). Because of increased humidity inside the canopy, narrower spacing led to a higher incidence of $B$. cinerea on strawberry fruit (Legard et al. 2000).

Incidence of infection of artificially inoculated strawberry flowers and subsequent fruit rot increased with the increased duration of wetness (up to $32 \mathrm{~h}$ ) at all temperatures $\left(5-30^{\circ} \mathrm{C}\right.$ ) (Bulger et al. 1987). The optimum temperature for flower infection is about $20^{\circ} \mathrm{C}$; both flower and fruit infections were greatly reduced at temperature above $25^{\circ} \mathrm{C}$ or below $15^{\circ} \mathrm{C}$. Several models were derived to relate inoculum (number of trapped conidia) and weather conditions to the incidence of flower infection ( $\mathrm{Xu}$ et al. 2000), with the models using both weather variables and inoculum giving the best predictions. Day vapour pressure deficit and night temperature are the most important weather variables affecting flower infection. Reduced risk of grey mould under protection (Creemers et al. 2006; Evenhuis and Wanten 2006; Xiao et al. 2001) is most likely due to the 
protection of flowers and fruit from rainfall, and hence reduced humidity.

As expected, incidence of fruit infection following inoculation of mature fruit increased with increasing duration of wetness (Gilles 1959). The conditions required for infection of ripe fruit are not as stringent as for infection of flower parts (Bulger 1986; Ellis et al. 1991). The incidence of fruit infection was better described by petal necrosis than by stamen necrosis (Bulger et al. 1987). In field crops of raspberry, correlations were found between post-harvest grey mould and high relative humidity in the 5-day period before picking and rainfall during picking (Jarvis 1964).

\subsection{Recent development in related research on B. cinerea}

Recently, there have been three significant developments in understanding $B$. cinerea epidemiology on various plant species that may have direct applications on strawberry and raspberry grey mould research. A method based on the TaqMan PCR was developed for detection and quantification of latent $B$. cinerea infections in plant tissue, which allows very specific and sensitive testing of plants for fungal DNA (Suarez et al. 2005). It has been shown that long-term symptomless (systemic) infection can occur throughout plants in primula (Barnes and Shaw 2003) and lettuce (Sowley et al. 2010). The latter study shows that $B$. cinerea commonly grows in lettuce plants as an endophyte. If this is true for other hosts, further research is needed to assess whether the endophytic phase may be as important a component of the species population as the aggressive necrotrophic phase. Populations of $B$. cinerea may be structured according to host and geographic location (Alfonso et al. 2000; Rajaguru and Shaw 2007) although molecular characterisation of fungal isolates has clearly shown the importance of external inoculum in shaping epidemic development (Decognet et al. 2009).

\section{Materials and methods}

Experiments were conducted to determine the relationship of the incidence of flower infection with weather condition and the incidence of latent and post-harvest grey mould in commercial raspberry and strawberry crops grown under protection.

\subsection{Flower infection}

The incidence of infection of raspberry flowers was determined in 2007 and 2008 in two unsprayed crops (one in Kent and the other in Cambridgeshire, England) of cv. Glen Ample. The two sites are about $180 \mathrm{~km}$ apart. The crop was covered in February in each year whilst flowering time was between early May and mid-June. The flowers sampled were surface sterilised with $10 \mathrm{ml}$ sodium hypochlorite $(0.025 \%$ available chlorine $(w / v))$ for $15 \mathrm{~min}$ on a shaker to remove any spores on the surface and then rinsed several times with distilled water. The flowers were placed separately on a piece of filter paper thoroughly wetted with distilled water in sterile Petri dishes (diameter: $5 \mathrm{~cm}$ ). The dishes were incubated at ambient temperatures of approximately $20^{\circ} \mathrm{C}$ for $10-14$ days before individual flowers were examined for the presence of $B$. cinerea conidiophores. Any flower on which conidiophores were detected was classified as infected.

A USB 502 logger (Measurement Computing, Norton, MA, USA) was installed at the canopy height (ca. $1 \mathrm{~m}$ for raspberry and ca. $20 \mathrm{~cm}$ for strawberry) to record temperature $\left({ }^{\circ} \mathrm{C}\right)$ and rh in the tunnel at an interval of $30 \mathrm{~min}$. Values of vapour pressure deficit (vpd, $\mathrm{mmHg}$ ) were derived from temperature (T) and rh using the following empirical equation: $v p d=4.6698 \mathrm{e}^{0.06241 \mathrm{~T}}(1-\mathrm{rh} / 100)$.

The incidence of flower infection was similarly determined over 3 years (2007-2009) in one unsprayed strawberry crop of cv. Elsanta (June-bearer) in Kent, England; a different crop was used in each year. The crop was covered in February in each year whilst flowering time was between mid-April and mid-May. During the flowering period, flowers were sampled every few days. On each sampling day (between 07:30 and 08:30 GMT), 100 fully opened flowers with all petals still attached (no necrosis on them) were randomly collected individually into $25 \mathrm{ml}$ universal bottles on each crop. Within each season, 11-17 batches of flowers were sampled.

\subsection{Occurrence of latent infection, and visual} and post-harvest grey mould

Data on the incidence of grey mould on raspberry plantations grown in open-field and under protection was obtained from fruit in random samples of commercial crops across the UK. Samples of raspberry fruit were taken in 2007 from 19 crops of cvs. Glen Ample and Tulameen. Each crop was sampled twice: initially to obtain unripe yellow fruit and then to collect ripe fruit. The aim was to examine fruit for any relationship between latent infection in yellow fruit and post-harvest grey mould on ripe fruit. The first sample of unripe yellow fruit was taken 2 weeks after the start of commercial harvesting; 100 lateral branches were cut from the canes in each crop. Unripe yellow fruit were surface sterilised with $10 \mathrm{ml}$ sodium hypochlorite $(0.025 \%$ available chlorine $(w / v))$ for $15 \mathrm{~min}$, rinsed 
several times with distilled water, and then placed on paraquat chloramphenicol agar (Peng and Sutton 1991), and incubated under ambient temperature for 1-2 weeks before assessment for $B$. cinerea. For assessment of postharvest grey mould, 100 ripe marketable fruit were taken from the same crop rows 2 weeks after the first sampling, placed onto multicell trays, incubated and assessed as described for strawberry.

Data on the incidence of grey mould on strawberry grown under protection was obtained from the untreated and fungicide-treated plots in several fungicide efficacy trials against grey mould at East Malling Research over several years. The fungicide-treated plots received three to five fungicide applications, starting at first flower and then at an interval of 7-10 days; the precise flowering time varied with years and the crop type (open field or protected). In two trials, only the latent infection by B. cinerea in immature fruit was determined, whereas in four other trials the incidence of post-harvest grey mould was assessed. In all trials, any fruit with visual grey mould symptoms at harvest was recorded as well. One site used in 2009 and 2010 was used for estimating the incidence of flower infection as well as latent fruit infection.

For assessing latent infection, immature yellow fruit were randomly sampled from each crop, surface-sterilised by immersing in $0.025 \% \mathrm{w} / \mathrm{v}$ sodium hypochlorite for $15 \mathrm{~min}$, rinsed several times in sterile distilled water, and then placed onto multicell trays (leaving space between each fruit). Each tray was sealed within a polythene bag and incubated at $20^{\circ} \mathrm{C}$ under a diurnal light/dark regime for 23 weeks before assessment. For assessment of post-harvest grey mould, ripe fruit were sampled and transferred to multicell trays without surface sterilisation. The tray was then sealed in a polythene bag and exposed to a continuous light regime at ambient temperature for 7 days prior to assessment for $B$. cinerea. Visual grey mould symptoms were assessed on a random sample of ripe fruit in situ. Within each trial, the incidence of visual grey mould, or latent infection, or post-harvest grey mould was assessed at several time points; at each time, at least 100 fruit were sampled/assessed.

\subsection{Data analysis}

The observed percentage of infection of raspberry and strawberry flowers was first compared to the predicted value given by a previously published model based on average daily (08:00 GMT to 07:59 GMT next day) temperature and vpd, i.e. model 5 as described by $\mathrm{Xu}$ et al. (2000). The model predicts daily incidence of infected flowers $\left(\mathrm{PI}_{t}\right)$ using the equation: $\ln \left(P_{t} /(1-\right.$ $\left.\left.P_{t}\right)\right)=-5.33-0.964 \times \mathrm{vpd}+0.509 \times$ temperature. To compare the observed incidence with the predicted, we assumed that sampled flowers were exposed (and susceptible) to $B$. cinerea for the previous $48 \mathrm{~h}$ prior to sampling. Thus, the predicted incidence of flower infection $\left(\mathrm{PBI}_{t}\right)$ for the batch of flowers sampled on day $t$ is

$\mathrm{PBI}_{t}=\mathrm{PI}_{t-2}+\left(1-\mathrm{PI}_{t-2}\right) \mathrm{PI}_{t-1}$

where $\mathrm{PI}_{t-1}$ and $\mathrm{PI}_{t-2}$ are the predicted daily infection on day $t-1$ and $t-2$, respectively. Pearson's and Spearman correlation coefficients were calculated to assess the correlation between the predicted and observed incidences of flower infections.

We also tried to develop a new model for infection of raspberry flowers, relating the incidence of flower infection to weather conditions. As pointed out previously (Xu et al. 2000), a straight regression of the incidence of flower infection in each 48-h period on corresponding averages of weather variables was not appropriate. We adopted the same modelling approach as used previously for developing strawberry flower infection models (Xu et al. 2000) to determine the effects of weather variables on the incidence of daily flower infection. The logit of daily incidence of flower infection $\left(\mathrm{DII}_{t}\right)$ was first assumed be linearly related to (i.e. function of) daily weather variables, i.e. $\ln \left(\mathrm{DII}_{t} /\left(1-\mathrm{DII}_{t}\right)\right)=f\left(w_{t}\right)$, leading to $\mathrm{DII}_{t}=\frac{\exp \left(f\left(w_{t}\right)\right)}{1+\exp \left(f\left(w_{t}\right)\right)}$. However, the daily incidence of flower infection $\left(\mathrm{DII}_{t}\right)$ was not available in the present datasets. Instead, under the assumption that sampled flowers were exposed to infection for the previous $48 \mathrm{~h}$ prior to sampling, the incidence of flower infection $\left(p_{t}\right)$ for each batch of flowers sampled on day $t$ was related to $\mathrm{DII}_{t}$ :

$$
\begin{aligned}
p_{t}= & \frac{\exp \left(f\left(w_{t-2}\right)\right)}{1+\exp \left(f\left(w_{t-2}\right)\right)}+\left(1-\frac{\exp \left(f\left(w_{t-2}\right)\right)}{1+\exp \left(f\left(w_{t-2}\right)\right)}\right) \\
& \times \frac{\exp \left(f\left(w_{t-1}\right)\right)}{1+\exp \left(f\left(w_{t-1}\right)\right)}
\end{aligned}
$$

Equation 2 was fitted to the observed data using the FITNONLINEAR procedure, which estimates parameters using the maximum likelihood method in Genstat ${ }^{\mathrm{TM}}$ (Payne 2006). The following weather variables were included in the regression analysis: temperature, rh and vpd. For each variable, day (08:00 GMT to 19:59 GMT) and night (20:00 GMT to 07:59 GMT the next day) averages as well as daily (08:00 GMT to 07:59 GMT the next day) averages were used. Models involving all combinations of up to four weather variables were fitted to the data, and the best model was selected based on the percentage of variation of accounted for, number of variables, and analysis of residuals.

Generalised linear modelling (GLM) was used to determine whether the incidence of raspberry fruit in commercial crops was affected by factors, such as protected/unprotected and sprayed/unsprayed. This analysis 
assumed that the proportion $(p)$ of infected fruit per sample is binomially distributed (Cox and Snell 1989). Genstat (Payne 2006) was used for statistical analysis. Similarly, GLM analysis was applied to the overall incidence of latent infection, and visual and post-harvest grey mould on strawberry fruit. In this analysis, all treatments of different fungicides were treated as a single treatment and compared with the untreated for each type of grey mould and different trials treated as blocks. This is necessary since fungicide treatments differed between years.

\section{Results}

\subsection{Raspberry}

\subsubsection{Infections of flowers}

As expected, there was greater variability in the daytime conditions than in the night time in both years. There were similarities in the overall weather patterns between the two sites despite some differences. As an example, Fig. 1 plots out average daytime temperature, rh and vpd values in two raspberry crops where flower infection was monitored in 2007, indicating similar patterns between the two sites; average day temperature ranged from $10^{\circ} \mathrm{C}$ to $29^{\circ} \mathrm{C}$, rh from $40 \%$ to $90 \%$, and vpd from 1 to $18 \mathrm{mmHg}$.
Similarly, the incidence of flower infection varied greatly among sampling occasions for both sites within each year (Fig. 2). At the Kent site, the incidence in 2007 ranged from $2 \%$ on $23 / 05$ to nearly $56 \%$ on $30 / 05$ (average $=23 \%$ ); at the Cambridge site, it ranged from $1 \%$ on $14 / 05$ to $51 \%$ on $18 / 06$ (average $=18 \%$ ). In 2008 , it ranged from $4 \%$ to $50 \%$ (average $=15 \%$ ) at the Kent site and from $2 \%$ to $39 \%$ (average $=17 \%$ ) at the Cambridge site.

In general, the previously published model considerably overestimated the level of infection of raspberry flowers. Moreover, the overall trend of predicted infection did not follow the observed pattern for all four datasets. For example, the average observed flower infection at the Kent site in 2007 was $23 \%$, compared to the corresponding predicted average of $53 \%$. At both sites in 2007, the model predicted high incidences of infection during the period of early to mid-June (Fig. 2a, b) because of high humidity (low vpd; Fig. 1). However, only at the Cambridge site did the observed incidence increase during this period (Fig. 2b). Both Pearson's correlation and Spearman's rank correlation coefficients between observed and predicted incidences were not significantly different from zero for the 2007 Kent dataset and the 2008 Cambridge dataset. The positive correlation was close to the 5\% significance level for the 2007 Cambridge dataset and was significant $(P<0.01)$ for the 2008 Kent dataset (Fig. 2).
Fig. 1 Average day time (0800 GMT-1959 GMT) vapour pressure deficit (VPD, solid), temperature (dotted) and relative humidity (dotted dash) inside the raspberry crop canopy under protection in 2007 at the Kent and Cambridge sites where flowers were sampled for assessment of $B$. cinerea infection
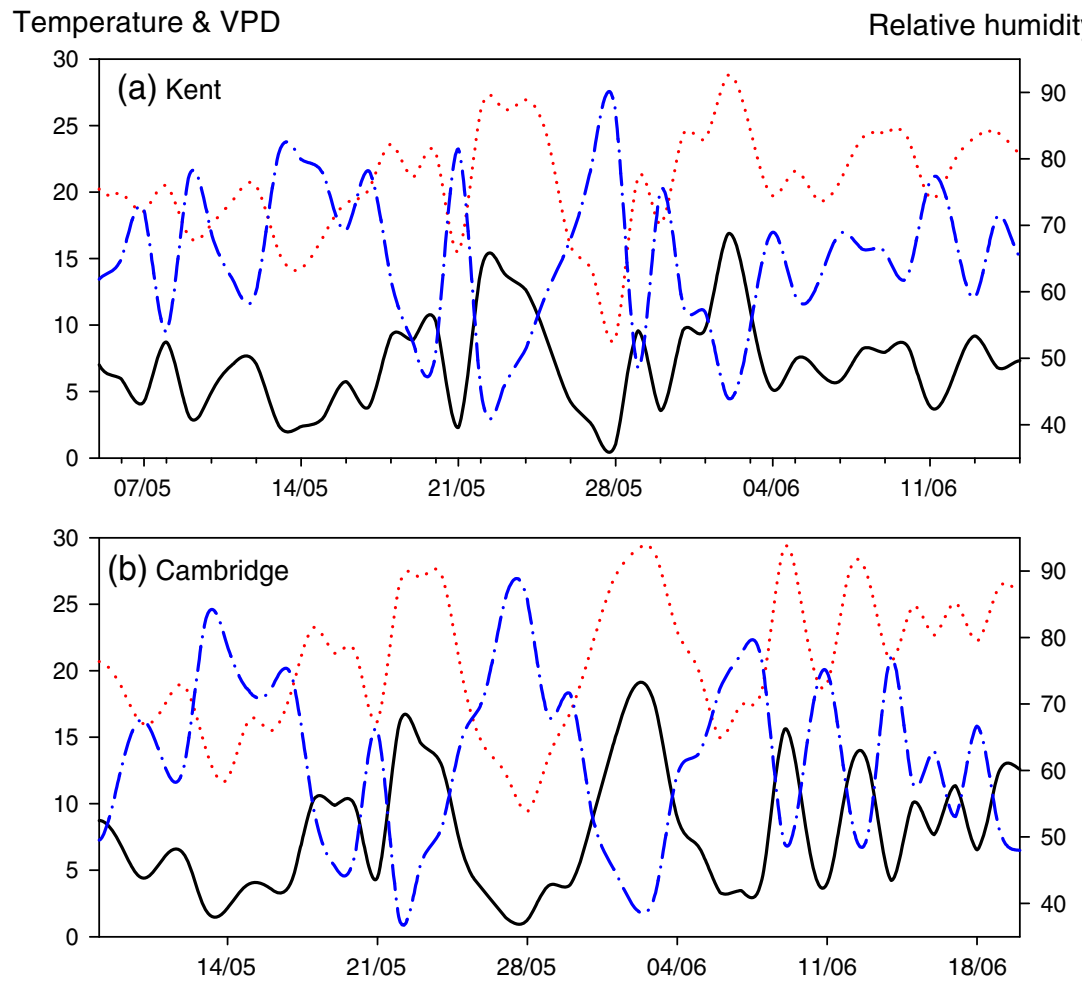
$\%$ flowers infected
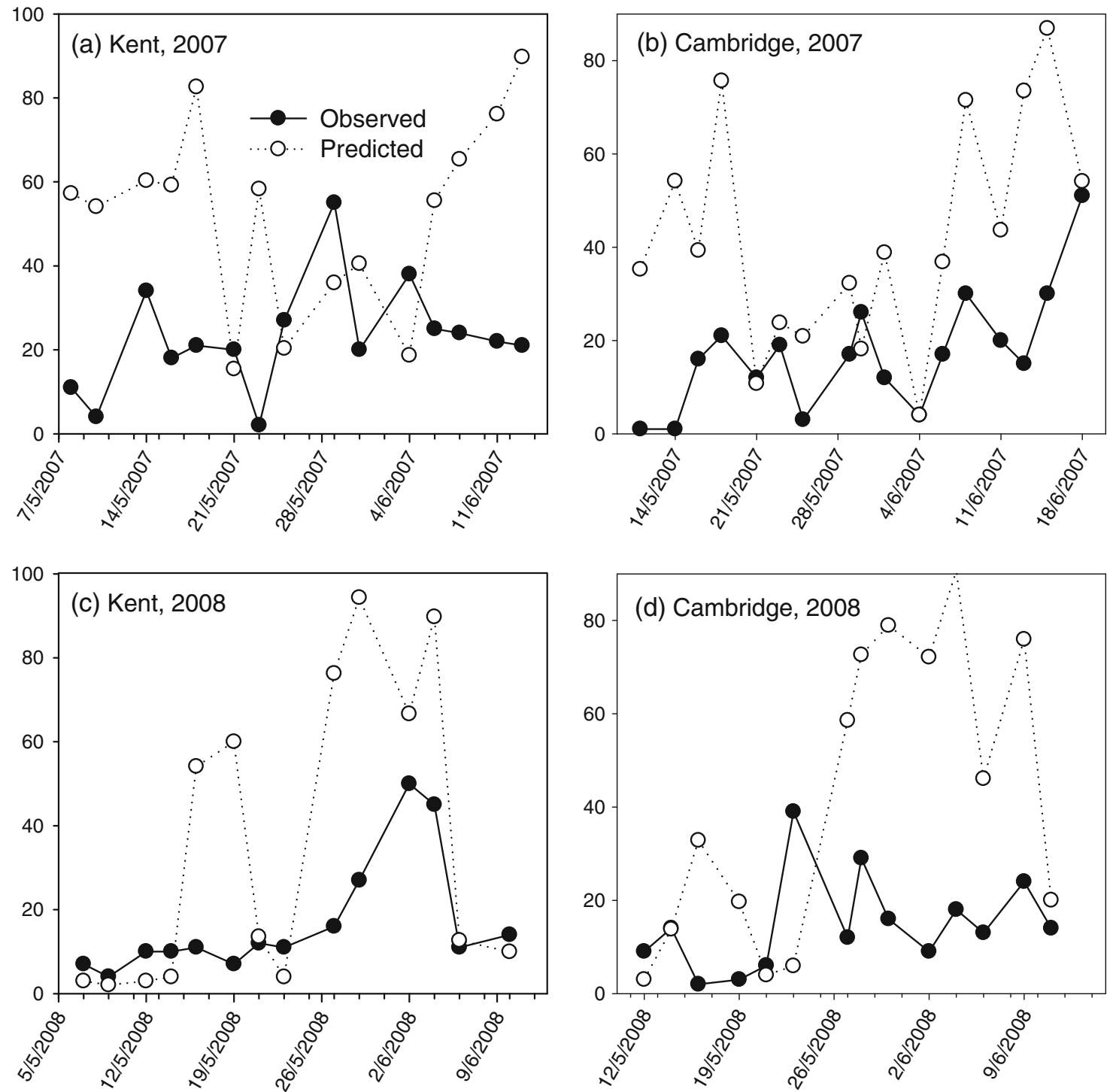

Fig. 2 The observed (filled circles) and predicted (open circles) incidence of infection by B. cinerea of raspberry flowers on each sampling day in 2007 and 2008 in an unsprayed tunnel at the Kent and Cambridge sampling sites

Table 1 presents a summary of the modelling results. A greater proportion of variance in the incidence of flower infection was explained by climatic variables in 2008 than in 2007 for both sites. Flower infection in 2007 appeared to be more influenced by temperature and in 2008 by moisture conditions. There were significant differences in the relationship between the incidence of flower infection and climatic variables between the Kent and Cambridge sites. Consequently, a single model derived from the four datasets only explained about $20 \%$ of the total variation in the observed incidences of flower infection. Incidence of flower infection at the Cambridge site appeared to be less related to any of the weather variables recorded than at the Kent site (Table 1).

\subsubsection{Latent B. cinerea infection and grey mould on raspberry fruit}

There were large differences between crop samples from commercial plantations in the incidence of latent infection in unripe fruit (Table 2), ranging from $0 \%$ to $99 \%$, and postharvest grey mould, ranging from $2 \%$ to $90 \%$. Many samples showed a high incidence $(>50 \%)$ of grey mould. On average, the incidence of latent infection and postharvest grey mould on sprayed $(55 \%, 46 \%)$, covered $(53 \%$, $43 \%)$ and cv. Glen Ample (54\%, 45\%) were less than on the respective unsprayed $(85 \%, 82 \%)$, uncovered $(65 \%$, $59 \%)$ and cv. Tulamen $(65 \%, 58 \%)$. However, because of large variation in the incidence of grey mould within each 
Table 1 Summary of modelling of infection of raspberry flower by $B$. cinerea in 2007 and 2008 in two unsprayed protected raspberry crops, cv. Glen Ample, in Cambridge and Kent

\begin{tabular}{lll}
\hline Datasets & Climatic variables included $^{\mathrm{a}}$ & $\begin{array}{l}\text { Percent variances } \\
\text { accounted for }\end{array}$ \\
\hline Cambridge in 2007 & $\mathrm{ADT}^{2} \mathrm{ADT}^{2}+\mathrm{ADT}^{1 / 2}$ & 19.6 \\
Kent in 2007 & $\mathrm{ADV}^{2}+\mathrm{ADT}^{1 / 2}+\mathrm{ADV} \times \mathrm{ADT}$ & 37.4 \\
Cambridge in 2008 & $\mathrm{NV}+\mathrm{NV} \times \mathrm{NT}+\mathrm{NT} \times \mathrm{NRH}$ & 54.3 \\
Kent in 2008 & $\mathrm{DV}+\mathrm{NT}+\mathrm{DV}^{1 / 2}$ & 69.4 \\
$2008^{\mathrm{b}}$ & $\mathrm{NT}+\mathrm{DRH}+\mathrm{DV}^{1 / 2}$ & 37.2 \\
All four datasets & $\mathrm{DT}+\mathrm{NT}+\mathrm{DT}^{2}+\mathrm{DT}^{1 / 2}$ & 20.0 \\
\end{tabular}

${ }^{a} D T$ day average temperature, $D V$ day average vapour pressure deficit, $D R H$ day average relative humidity, $N T$ night average temperature, $N V$ night average vapour pressure deficit, $N R H$ night average relative humidity, $A D T$ daily average temperature, $A D V$ daily average vapour pressure deficit, $A D R H$ daily average relative humidity

${ }^{\mathrm{b}}$ A combined model for 2007 data cannot be derived

group, these differences were not statistically significant. There was also no significant correlation between incidences of latent infection and post-harvest grey mould from each crop.

\subsection{Strawberry}

\subsubsection{Infections of strawberry flowers}

The observed percentage values of latent infection of flowers, together with that predicted by the published model, are plotted in Fig. 3 for all 3 years. In 2008, there was a very low level of latent infection (average $=7 \%$ ) except for one sample collected on 28/04/08 (Fig. 3a); for all other 11 samples, the observed incidence of flower infection was $\leq 5 \%$. In 2009 , the level of infection was generally higher than in 2008, ranging from $2 \%$ to $35 \%$ (average $=13 \%$; Fig. 3b). As in 2008, the level of latent infection of flowers was in 2010 very low, ranging from $0 \%$ to $6 \%$ (average $=1 \%$; Fig. $3 \mathrm{c}$ ).

The predicted incidence of flower infection is generally greater than the observed in all 3 years (Fig. 3). In 2008, the Pearson's correlation $(r=0.56)$ was significant at the $5 \%$ level but the Spearman's rank correlation $(r=0.39)$ was not. In 2009, both Pearson's and Spearman's rank correlation coefficients ( $r=0.65$ and 0.58 , respectively) were significant $(P<0.05)$. In 2010 , the predicted incidence of flower infection was low (especially for the early part of the flowering period), compared to 2008 and 2009, ranging from $0 \%$ to $24 \%$. However, the predicted incidences were
Table 2 Summary of crop details and incidence of latent $B$. cinerea in unripe raspberry fruit and post-harvest grey mould after 7-day incubation in random samples from 19 commercial crops in the UK

\begin{tabular}{|c|c|c|c|c|}
\hline \multirow[t]{2}{*}{ Variety } & \multirow[t]{2}{*}{ Crop type } & \multirow{2}{*}{$\begin{array}{l}\text { Fungicides used } \\
\text { against } B \text {. cinerea }\end{array}$} & \multicolumn{2}{|c|}{ Percent of fruit with $B$. cinerea } \\
\hline & & & Latent & Post-harvest \\
\hline Glen Ample & Covered-near harvest & Spray & 46 & 4 \\
\hline Glen Ample & Covered-rain sheets & Spray & 92 & 21 \\
\hline Glen Ample & Glasshouse & Spray & 24 & 44 \\
\hline Glen Ample & Open & None & 84 & 90 \\
\hline Glen Ample & Open & Spray & 10 & 46 \\
\hline Glen Ample & Open & Spray & 54 & 56 \\
\hline Glen Ample & Open & Spray & 99 & 64 \\
\hline Glen Ample & Open & Spray & 76 & 45 \\
\hline Glen Ample & Tunnel & Spray & 51 & 65 \\
\hline Glen Ample & Tunnel & Spray & 21 & 68 \\
\hline Glen Ample & Tunnel & Spray & 0 & 40 \\
\hline Glen Ample & Tunnel & Spray & 67 & 21 \\
\hline Glen Ample & Tunnel & Spray & 82 & 16 \\
\hline Tulameen & Covered—rain sheets & Spray & 99 & 50 \\
\hline Tulameen & Covered_rain sheets & Spray & 92 & 29 \\
\hline Tulameen & Open & None & 86 & 74 \\
\hline Tulameen & Open & Spray & 57 & 84 \\
\hline Tulameen & Open & Spray & 76 & 69 \\
\hline Tulameen & Tunnel & Spray & 61 & 63 \\
\hline Tulameen & Tunnel & Spray & 17 & 94 \\
\hline Tulameen & Tunnel & Spray & 34 & 2 \\
\hline
\end{tabular}



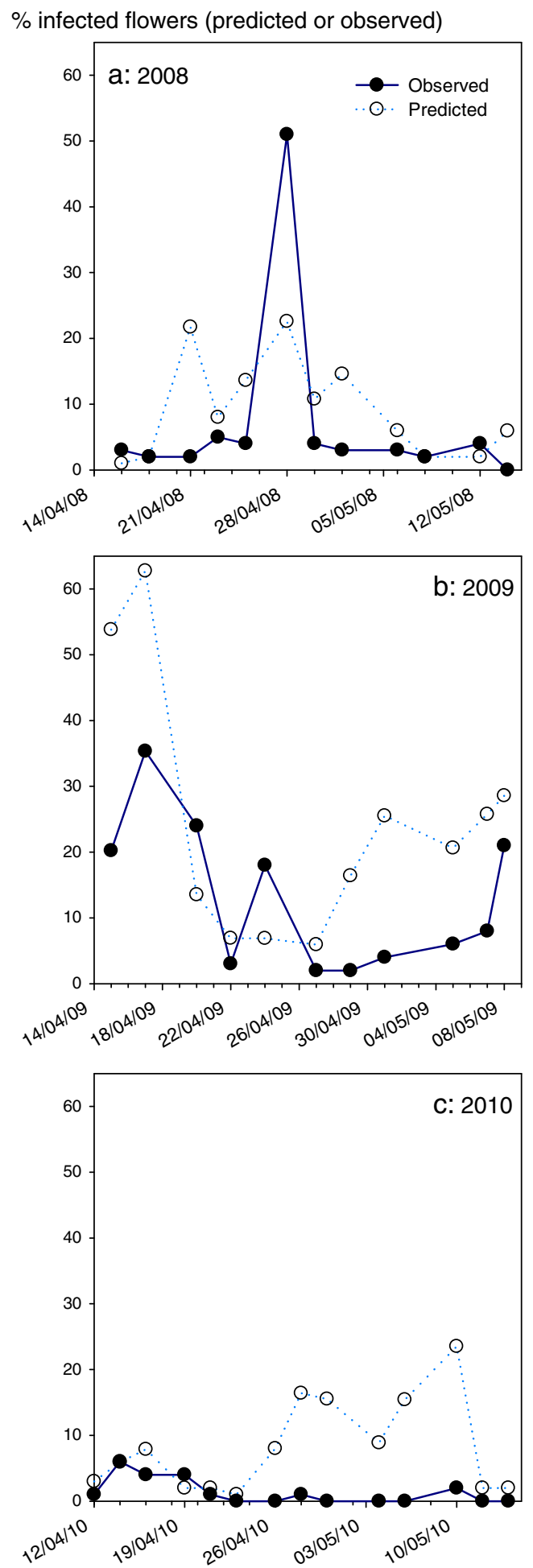

Fig. 3 The observed (filled circles) and predicted (open circles) incidence of $B$. cinerea infection of strawberry flowers on each sampling day in 2008-20010 in an unsprayed tunnel at a commercial farm

still higher than the observed for the second half of the sampling period (Fig. 3c). Neither Pearson's correlation nor Spearman's rank correlation was significantly greater than zero.

\subsubsection{Latent B. cinerea infection and grey mould on strawberry fruit}

In the two trials where the latent infection of fruit was estimated, the incidence of latent infection was very low with the overall incidence $<3 \%$ (Table 3 ). There were no statistical significant differences between fungicide-treated and untreated plots.

The incidence of fruit with visual grey mould symptom at harvest was very low in all trials (Table 3). In three of the five trials, no single fruit with visual grey mould was observed at harvest; whereas in the other two trials, incidences of fruit with visual grey mould at harvest were all $<7 \%$. There were virtually no differences in the incidence of fruit with visual grey mould at harvest between the unsprayed and fungicidetreated plots, as confirmed by GLM analysis.

The level of post-harvest grey mould varied greatly among three trials as well as among different picks within each trial (Table 3). In 2006, very few fruit had post-harvest grey mould. But in other trials, the incidence of postharvest grey mould ranged from $0 \%$ to $63 \%$. For trials in 2007-2009, the fungicide-treated plots had an overall lower incidence (ca. 17.6\%) of post-harvest grey mould than the untreated (33.3\%). GLM analysis of the four trials together indicated that the incidence of post-harvest grey mould was significantly lower on the fungicide-treated plants than on untreated plants. In all post-harvest rot assessments, in addition to B. cinerea other fungi, including Colletotrichum spp., Mucor spp., Rhizopus spp., and Penicillium spp., were also present on a varying number of fruit after 7-day incubation under ambient conditions.

\section{Discussion}

In the UK, both raspberry and strawberry are now mostly grown under protection to extend the production season and to protect fruit from rain so that fruit can be harvested irrespective of the weather and a supply to retailers maintained. However, control measures for fruit grey mould on protected crops are still primarily based on the strategy developed for open-field crops, i.e. scheduled applications of fungicides to control $B$. cinerea during the flowering and early fruiting period. This study has generated new data on the epidemiology of grey mould on raspberry and strawberry (June bearers) grown under protection, which has significant implications on whether such a management strategy is appropriate.

The overall incidence of flower infection and latent infection of fruit on raspberry was much higher than on strawberry, which may be explained by differences in inoculum and weather conditions between raspberry and strawberry. Inoculum sources comprise sclerotia on plant 
Table 3 Percentage of latent and visual grey mould at harvest, and post-harvest in strawberry fruit

\begin{tabular}{|c|c|c|c|c|c|c|c|c|}
\hline Treatment & Pick 1 & Pick 2 & Pick 3 & Pick 4 & Pick 5 & Pick 6 & Pick 7 & Overall \\
\hline \multicolumn{9}{|c|}{2006 Visual rot (post-harvest grey mould is very low; latent infection not assessed) } \\
\hline Untreated & 2.5 & 6.3 & 4.0 & 2.5 & & & & 3.8 \\
\hline Fungicide $1^{\mathrm{a}}$ & 6.7 & 6.7 & 3.5 & 3.5 & & & & 5.1 \\
\hline Fungicide 2 & 0 & 3.5 & 2.0 & 1.4 & & & & 1.7 \\
\hline \multicolumn{9}{|c|}{2007 Visual rot (latent infection not assessed) } \\
\hline Untreated & 2.0 & 2.4 & 1.1 & 2.1 & 1.3 & 1.4 & 1.8 & 1.7 \\
\hline Fungicide 1 & 0 & 1.8 & 1.8 & 1.2 & 4.0 & 0 & 0 & 1.3 \\
\hline Fungicide 2 & 0 & 0 & 1.6 & 0.6 & 0 & 0 & 0 & 0.2 \\
\hline Fungicide 3 & 2.7 & 0.8 & 1.1 & 2.0 & 1.9 & 0 & 0 & 1.2 \\
\hline \multicolumn{9}{|c|}{ Post-harvest grey mould } \\
\hline Untreated & 63.4 & 33.4 & 25.5 & 14.2 & 13.9 & 13.0 & & 27.3 \\
\hline Fungicide 1 & 41.5 & 24.3 & 17.4 & 7.5 & 5.6 & 6.4 & & 17.1 \\
\hline Fungicide 2 & 13.8 & 15.1 & 10.8 & 8.5 & 2.9 & 5.3 & & 9.4 \\
\hline Fungicide 3 & 50.8 & 23.1 & 20.6 & 11.7 & 10.7 & 6.3 & & 20.5 \\
\hline \multicolumn{9}{|c|}{2008 Post-harvest grey mould (no visual grey mould; latent infection not assessed) } \\
\hline Untreated & 39.4 & 43.6 & 33.1 & 38.0 & 42.0 & 40.2 & & 39.4 \\
\hline Fungicide 1 & 12.6 & 23.2 & 14.2 & 22.3 & 30.1 & 32.1 & & 22.4 \\
\hline Fungicide 2 & 19.9 & 26.8 & 16.0 & 23.0 & 33.4 & 23.5 & & 23.8 \\
\hline \multicolumn{9}{|c|}{2009 Trial 1: post-harvest grey mould (no visual grey mould; latent infection not assessed) } \\
\hline Untreated & 42.9 & 46.3 & 32.1 & 28.4 & 17.0 & & & 33.3 \\
\hline Fungicide 1 & 7.9 & 25.5 & 23.9 & 17.0 & 0 & & & 14.9 \\
\hline Fungicide 2 & 9.1 & 20.5 & 21.3 & 14.7 & 11.7 & & & 15.5 \\
\hline \multicolumn{9}{|c|}{2009 Trial 2: latent infection (no visual grey mould; post-harvest grey mould not assessed) } \\
\hline Untreated & 6.7 & 0 & 2.0 & 1.0 & & & & 2.4 \\
\hline Fungicide 1 & 4.6 & 0 & 1.0 & 0 & & & & 1.4 \\
\hline \multicolumn{9}{|c|}{ 2010: Latent infection (no visual grey mould; post-harvest grey mould not assessed) } \\
\hline Untreated & 9.4 & 0 & 0 & 1 & & & & 2.2 \\
\hline Fungicide 1 & 2.5 & 0 & 0 & 0 & & & & 0.8 \\
\hline
\end{tabular}

Data from experiments in 2006-2009 at East Malling Research on cv. Elsanta grown under protection. For all fungicide treatments, three to five sprays against $B$. cinerea were applied starting at first flower at an interval of 7-10 days, except for the 2009 trial 2 and the 2010 trial where only a single spray was applied

${ }^{a}$ Fungicide name are not given because most of these trials are subject to commercial confidentiality

debris, plant organs and weeds, and resting mycelia on several plant tissues (Jarvis 1962a, b, c; Braun and Sutton 1987; Mertely et al. 2000; Stromeng et al. 2009). On strawberry, inoculum level is likely to be lower than in raspberry because of plastic covering of planting beds very early in the season and use of straw mulch over pathways and soil. Moreover, strawberry crops usually only last for 1-2 years. In contrast, weeds and plant debris are much more abundant in raspberry crops because of their perennial nature and canopy structure. Raspberry crops under protection usually flower during the period from early May to mid-June, about a month earlier than the flowering time of June-bearer strawberry under protection sampled in this study. Thus, conditions for infection of flowers, especially the night temperature as identified for field- grown crops (Xu et al. 2000), may not be as limiting in raspberry as in June-bearer strawberry in this study. The high incidence of latent infection on raspberry might also be due to the possibility that $B$. cinerea grows in raspberry as an endophyte as recently found on lettuce (Sowley et al. 2010); further research is needed to understand this potential avenue of fruit rotting.

A previously published strawberry model $(\mathrm{Xu}$ et al. 2000) did not consistently predict the incidence of flower infections accurately over several seasons on both raspberry and strawberry crops grown under protection. Its predictions also appeared to over-estimate the incidence of flower infection. A single strawberry sample in 2008 with a very high percentage of flower infection may be partly caused by the fact that the crop was disturbed by the tractor laying 
straw between strawberry beds the day before the sampling. This may increase spore dispersal and potentially damage strawberry flowers. The inconsistent performance of the model predictions may have resulted from the nature of data from which the model was developed. The model was developed from the data collected from an open-field strawberry crop for which flowering is usually in the period from late April to early June. It identified temperature (primarily night time) and vapour pressure deficit (primarily day time) as two limiting factors for infection of flowers during this period. But for crops under protection, night time temperature during flowering is no longer expected to be a limiting factor for infection. Another reason may be the difference in the level of inoculum between crops grown in open-field and under protection. In open-field, sporulation of $B$. cinerea on plant residues in spring is expected to be much greater than under protection because of the protection of colonised plant residues from rain under protection.

It was not possible to develop a single model to relate the incidence of infection of raspberry flowers to weather factors. Not only the relationship of flower infection with climatic factors varied greatly among the four datasets, but the percentage of variance explained by each model also varied greatly among the datasets. These results suggest that factors other than temperature and humidity may need to be considered for some datasets. However, given the high level of latent infection in both sprayed and unsprayed fruit, it is doubtful that a predictive model for flower infection will be of any significant use in practical management of grey mould on raspberry under protection. No attempt was made to develop another model for infection of strawberry flowers under protection because of the low levels of disease observed over the 3 years.

Incidence of latent $B$. cinerea in raspberry fruit was greatest in unsprayed uncovered crops and least in sprayed covered crops. However, the reduction in the incidence under protection was not statistically significant, indicating that establishment of latent infection in raspberry fruit, resulting mainly from infection of flowers (McNicol et al. 1985), does not need free water, consistent with the high level of flower infection as observed from the frequent sampling. On sprayed crops under protection, the overall level of latent infection on raspberry as well as post-harvest grey mould on both raspberry and strawberry, though varying among crops, was still high, compared with the unsprayed. This suggests that frequent application of fungicides during the flowering and early fruiting period only partially controlled $B$. cinerea. Some of post-harvest grey mould may also have resulted from new infections from conidia post-harvest, which was supported by the observations in this study that most fungal rots (including grey mould) appeared during the period of 4-7 days after harvest (data not shown). This post-harvest infection by $B$. cinerea may also explain the lack of correlation between the incidence of latent infection in yellow fruit and grey mould in ripe fruit on raspberry.

This study confirms that risk of grey mould on strawberry is greatly reduced under protection, compared with open-field (Xiao et al. 2001; Evenhuis and Wanten 2006) a result similar to that reported for red currant (Creemers et al. 2006). The level of flower infections was low on strawberry under protection and similarly the overall level of latent infection on unripe fruit was close to zero for both fungicide-treated and non-treated strawberry plants. On the other hand, a higher level of flower infection was found on raspberry under protection and the incidence of latent infection of unripe raspberry fruit grown in open field and under protection was high even for fungicide-treated crops. Most importantly, the level of ripe fruit with visual grey mould at harvest was very low, close to zero, for both strawberry and raspberry grown under protection. Although a high level of post-harvest grey mould was observed after incubation for 7 days, most fruit were also infected by other fungi anyway if not by $B$. cinerea already. Considering all these findings together, we question the need and value of fungicide application during the flowering and early fruiting period to control grey mould on raspberry and June-bearer strawberry crops grown under protection.

We concluded that fungicide control of grey mould during the flower and fruiting period on raspberry and June-bearer strawberry crops that are covered with plastics early in spring is not necessary. Furthermore, canopy manipulation is also not necessary on raspberry since it did not result in any appreciable reductions in the infection of raspberry fruit by B. cinerea (O'Neill et al. 2009), in contrast to results obtained on bunch rot of grape caused by B. cinerea (Zoecklein et al. 1992; English et al. 1993; Duncan et al. 1995). A varying level of post-harvest fungal rotting, including $B$. cinerea, suggests that, apart from usual crop hygienic practices, the post-harvest fruit management (e.g. rapid cooling and speedy delivery to selling points) is the key to prevent visible grey mould and other fungal rot from becoming visible before consumption (normally the time from harvest to consumption for both strawberry and raspberry is less than 7 days), i.e. extending the fruit shelf life. If fungicides applied outside of the flowering and fruiting period can provide adequate control of other diseases, it is possible to produce raspberry and strawberry fruit with zero (i.e. non-detectable) fungicide residues in fruit at harvest. Currently, this new strategy for grey mould control is being evaluated on several commercial crops sites in which fungicides are not applied during the flowering and fruiting period to control grey mould, but an efficient post-harvesting handling protocol is adopted. 
Acknowledgments Funding from Defra, SEERAD, HDC, Marks \& Spencer plc. The Worshipful Company of Fruiterers and the EM Trust for Horticultural Research is gratefully acknowledged. We are also grateful to the growers and soft fruit marketing companies who supported us in the conduct of field experiments. The projects were lead by John Place, Place UK and Hugh Mowat, Marks \& Spencer plc. Adam Shorter, Andrew Chesson and Paul Harrold hosted trials on their farms. Tim Newton, Berry World, Richard Harnden, KG Fruits and Adrian Wallbridge and James Carew, Summer Fruit Company provided essential support.

\section{References}

Alfonso C, Raposo R, Melgarejo P (2000) Genetic diversity in Botrytis cinerea populations on vegetable crops in greenhouses in south-eastern Spain. Plant Pathol 49:243-251

Barnes SE, Shaw MW (2003) Infection of commercial hybrid primula seed by Botrytis cinerea and latent disease spread through the plants. Phytopathology 93:573-578

Blanco C, de los Santos B, Romero F (2006) Relationship between concentrations of Botrytis cinerea conidia in air, environmental conditions, and the incidence of grey mould in strawberry flowers and fruits. Eur J Plant Pathol 114:415-425. doi:10.1007/s10658006-0007-3

Boff P, Kastelein P, de Kraker J, Gerlagh M, Kohl J (2001) Epidemiology of grey mould in annual waiting-bed production of strawberry. Eur J Plant Pathol 107:615-624

Borecka H, Millikan DF (1973) Stimulatory effect of pollen and pistillate parts of some horticultural species upon the germination of Botrytis cinerea spores. Phytopathology 63:1431-1432

Braun PG, Sutton JC (1987) Inoculum sources of Botrytis cinerea in fruit rot of strawberries in Ontario. Can J Plant Pathol 10:133-141

Braun PG, Sutton JC (1988) Infection cycles and population dynamics of Botrytis cinerea in strawberry leaves. Can J Plant Pathol 10:133-141

Bristow PR, McNicol RJ, Williamson B (1986) Infection of strawberry flowers by Botrytis cinerea and its relevance to grey mould development. Ann Appl Biol 109:545-554

Bulger MA (1986) The influence of temperature and wetness duration on the infection of strawberry flowers and fruit by Botrytis cinerea. Ohio State University, Columbus

Bulger MA, Ellis MA, Madden LV (1987) Influence of temperature and wetness duration on infection of strawberry flowers by Botrytis cinerea and disease incidence of fruit originating from infected flowers. Phytopathology 77:1225-1230

Cox DR, Snell EJ (1989) Analysis of binary data. Chapman and Hall, London

Creemers P, van Laer S, Pitsioudis F, Meeste P (2006) Evaluation of chemical control of Botrytis cinerea in relation to covering red currant shrubs. Agric Conspec Sci 71:115-119

Decognet V, Bardin M, Trottin-Caudal Y, Nicot PC (2009) Rapid change in the genetic diversity of Botrytis cinerea populations after the introduction of strains in a tomato glasshouse. Phytopathology 99:185-193

Duncan RA, Stapleton JJ, Leavitt GM (1995) Population dynamics of epiphytic mycoflora and occurrence of bunch rots of wine grapes as influenced by leaf removal. Plant Pathol 44:956-965

Ellis MA, Madden LV, Dale A, Luby JJ (1991) Progress in the development of disease forecasting systems for strawberry fruit rots in Ohio, The strawberry into the 21st century: Proceedings of the Third North American Strawberry Conference Houston, Texas, 244-251

English JT, Kaps ML, Moore JF, Hill J, Nakova M (1993) Leaf removal for control of Botrytis bunch rot of wine grapes in the Midwestern United States. Plant Dis 77:1224-1227
Evenhuis A, Wanten P (2006) Effect of polythene tunnels and cultivars on grey mould caused by Botrytis cinerea in organically grown strawberries. Agric Conspec Sci 71:111-114

Gilles G (1959) Biology and control of Botrytis cinerea Pers. on strawberries, Hofchen-briefe 3

Haegermark U (1984) Studies of grey mould (Botrytis cinerea Pers ex Nocca \& Balbis) infections on strawberry green fruit in cv. Senga Sengana Vaxskyddsnotiser 47:81-88

Hennebert GL, Gilles GL (1958) Epidemiologie de Botrytis cinerea Pers. sur frasiers, Mededelingen van de Faculteit Landbouwwetenschappen. Universiteit Gent 23:864-888

Hockey JF (1952) Grey mould wilt of raspberry. Sci Agric 32:150-152

Jarvis WR (1962a) The dispersal of spores of Botrytis cinerea Fr. in a raspberry plantation. Trans Br Mycol Soc 45:549-559

Jarvis WR (1962) The epidemiology of Botrytis cinerea Pers. in strawberries, XVIth International Horticultural Congress, Brussels, Belgium, pp. 258-262

Jarvis WR (1962c) The infection of strawberry and raspberry fruits by Botrytis cinerea Fr. Ann Appl Biol 50:569-575

Jarvis WR (1964) The effect of some climatic factors on the incidence of grey mould of strawberry and raspberry fruit. Hortic Res 3:65-71

Jarvis WR, Borecka H (1968) The susceptibility of strawberry flowers to infection by Botrytis cinerea Pers. ex Fr. Hortic Res 8:147-154

Jennings DL, Carmichael E (1975) Resistance to grey mould (Botrytis cinerea $\mathrm{Fr}$ ) in red raspberry fruits. Hortic Res 14:109-115

Kerling LCP (1964) Fungi in the phyllospere of leaves of rye and strawberry. Med Landb Hogesch Opzoekstns Gent 29:885-895

Kovacs G (1968) Etude de l'infection du fraisier par Botrytis cinerea Pers. et des modalites de lutte, Den KGL. Veterinaer OG Landbohhojkoles Arsskrift 89:84-99

Legard DE, Xiao CL, Mertely JC, Chandler CK (2000) Effects of plant spacing and cultivar on incidence of Botrytis fruit rot in annual strawberry. Plant Dis 84:531-538

McNicol RJ, Williamson B, Dolan A (1985) Infection of red raspberry styles and carpels by Botrytis cinerea and its possible role in post-harvest grey mould. Ann Appl Biol 106:49-53

Mertely JC, Chandler CK, Xiao CL, Legard DE (2000) Comparison of sanitation and fungicides for management of Botrytis fruit rot of strawberry. Plant Dis 84:1197-1202

Miller PM, Waggoner PE (1957) Dispersal of spores of Botrytis cinerea among strawberries. Phytopathology 47:24-25

O'Neill T, Berrie AM, Wedgwood E, Allen J, Xu XM (2009) Effect of canopy manipulation on cane and fruit Botrytis in protected raspberry. Commun Agric Appl Biol Sci 74:633-643

Payne RW (ed) (2006) The guide to GenStat ${ }^{\circledR}$ release 9 - Part 2: Statistics, VSN International. Hemel Hempstead, UK

Peng G, Sutton JC (1991) Evaluation of microorganisms for biocontrol of Botrytis cinerea in strawberry. Can J Plant Pathol $13: 247-257$

Powelson RL (1960) Initiation of strawberry fruit rot caused by Botrytis cinerea. Phytopathology 50:491-494

Rajaguru AP, Shaw MW (2007) Molecular ecology of systemic Botrytis cinerea. Phytopathology 97:S96-S96

Sowley ENK, Dewey FM, Shaw MW (2010) Persistent, symptomless, systemic, and seed-borne infection of lettuce by Botrytis cinerea. Eur J Plant Pathol 126:61-71

Stromeng GM, Hjeljord LG, Stensvand A (2009) Relative contribution of various sources of Botrytis cinerea inoculum in strawberry fields in Norway. Plant Dis 93:1305-1310

Suarez M, Walsh K, Boonham N, O’Neill T, Pearson S, Barker I (2005) Development of real-time PCR (TaqMan) assays for the detection and quantification of Botrytis cinerea in planta. Plant Physiol Biochem 43:890-899

Sutton J (1998) Botrytis fruit rot (gray mould) and blossom blight. In: Maas J (ed) Compendium of strawberry diseases. APS, St Paul, pp 28-31 
Wilcox WF, Seem RC (1994) Relationship between strawberry gray mould incidence, environmental variables, and fungicide applications during different periods of the fruiting season. Phytopathology $84: 264-270$

Williamson B (1991) Cane Botrytis. In: Ellis M, Converse R, Williams R, Williamson B (eds) Compendium of raspberry and blackberry diseases and insects. American Phytopathological Society, St. Paul, pp 10-11

Williamson B, Jennings DL (1986) Common resistance in red raspberry to Botrytis cinerea and Didymella applanata, two pathogens occupying the same ecological niche. Ann Appl Biol 109:581-593

Xiao CL, Chandler CK, Price JF, Duval JR, Mertely JC, Legard DE (2001) Comparison of epidemics of Botrytis fruit rot and powdery mildew of strawberry in large plastic tunnel and field production systems. Plant Dis 85:901-909

Xu X-M, Harris DC, Berrie AM (2000) Modelling infection of strawberry flowers by Botrytis cinerea using field data. Phytopathology 90:1367-1374

Xu X-M, Wedgwood E, Berrie AM, O'Neill T (2009) Infection of raspberry leaves by Botrytis cinerea in relation to leaf and cane age. Commun Agric Appl Biol Sci 74:761-770

Zoecklein BW, Wolf TK, Duncan NW, Judge JM, Cook MK (1992) Effects of fruit zone leaf removal on yield, fruit composition, and fruit rot incidence of Chardonnay and white riesling (Vitis vinifera L) grapes. Am J Enol Vitic 43:139-148 